\title{
CD22 Expressing Cell Count
}

National Cancer Institute

\section{Source}

National Cancer Institute. CD22 Expressing Cell Count. NCI Thesaurus. Code C111148.

The determination of the amount of CD22 expressing cells per unit present in a sample. 